Research Article

\title{
Study on Evolution Characteristics of Regenerated Roof Structure in Downward Mining of Bifurcated Coal Seam
}

\author{
Ru Hu $\mathbb{D}^{1},{ }^{1,2}$ Jiwen Wu $\left(\mathbb{D},{ }^{2}\right.$ WenBao Shi $\mathbb{D}^{3},{ }^{3}$ Xiaorong Zhai $\mathbb{D}^{2},{ }^{2}$ and Kai Huang ${ }^{2}{ }^{2}$ \\ ${ }^{1}$ State Key Laboratory of Mining Response and Disaster Prevention and Control in Deep Coal Mines, \\ Anhui University of Science and Technology, Huainan 232001, China \\ ${ }^{2}$ School of Earth and Environment, Anhui University of Science and Technology, Huainan 232001, China \\ ${ }^{3}$ School of Mining Engineering, Anhui University of Science and Technology, Huainan 232001, China \\ Correspondence should be addressed to Jiwen Wu; 564473701@qq.com
}

Received 12 July 2021; Accepted 13 August 2021; Published 31 August 2021

Academic Editor: Xin Cai

Copyright (c) $2021 \mathrm{Ru} \mathrm{Hu}$ et al. This is an open access article distributed under the Creative Commons Attribution License, which permits unrestricted use, distribution, and reproduction in any medium, provided the original work is properly cited.

\begin{abstract}
In recent years, the structural evolution characteristics of the regenerated roof of the lower coal seam have become a research hotspot when the bifurcation coal seam is mined downward. In this paper, taking the bifurcation coal seam of Xutuan Coal Mine in China as an example, the structural evolution characteristics of regenerated roof under the influence of mining in bifurcation coal seam are comprehensively studied by theoretical analysis, field measurement, and indoor similar simulation experiment. The stress transfer law in the floor after mining in the upper coal seam is also analyzed. The results show the overburden structure and stress field change caused by upper coal seam mining. The caving and fracture zones are formed in the roof, the average height of the caving zone is $8.28 \mathrm{~m}$, and the one of the fracture zone is $34.91 \mathrm{~m}$. The results of the field test verify the accuracy of theoretical analysis and similar simulation test results. According to the relative size of the depth of the strong failure zone of the coal seam floor and the coal seam spacing, the rock mass structure of the regenerated roof of lower coal seam is divided into three types: fractured rock mass + scattered rock mass (I), fractured rock mass + scattered rock mass + fractured rock mass (II), and fractured rock mass + bulk rock mass + fractured rock mass + layered rock mass (III), and the stability of the three types of regenerated roof structure is evaluated: III > II > I. The research in this paper can provide a theoretical basis for determining the target area of broken roof control under the mining conditions of bifurcation coal seam and provide guidance for the selection of the location and parameters of the grouting borehole for roof reinforcement.
\end{abstract}

\section{Introduction}

The formation process of coal is accompanied by complex paleo-sedimentary environmental changes. It is affected by multistage tectonic movements, eventually forming underground coal seams with different spatial forms. Bifurcation coal seam is one of these forms. As shown in Figure 1, the interlayer distance of bifurcation coal seam can vary from zero meters to tens of meters. This formation is a kind of close coal seam, but different from the traditional concept of close coal seam, mainly due to the gradual change of the distance between the upper and lower coal layers. This special form influences significantly the mining of the lower coal seam. When the distance between the two layers is small, the upper coal seam mining will produce mining damage to the floor, resulting in the destruction of the roof of the lower layer, which can be transformed from the original layered complete structure roof to a broken roof. When mining the lower coal seam, the roadway deformation is serious, being difficult to be supported, the broken roof of the working face cannot be easily managed, and roof safety accidents often occur, threatening the efficiency of the mine and the safety of the workers on-site $[1,2]$.

Scientists from all over the world have carried out many theoretical research studies on mining and engineering geological problems in the process of short distance coal seam mining and obtained fruitful results. When the close distance coal seam is mined downward, stress concentration occurs at the residual coal pillar of the upper working face, which has a great impact on the mining of the lower coal 


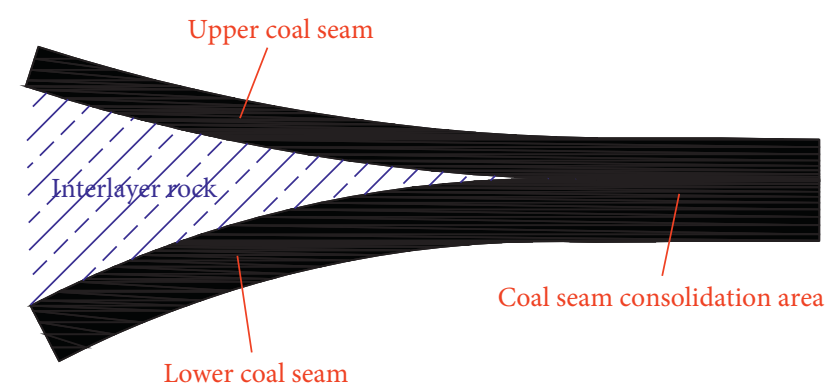

Figure 1: Diagram of bifurcation coal seam.

seam. Many scholars have carried out research on this problem [3-11], determined a reasonable size of coal pillar, scientifically designed the position of coal roadway and rock roadway, analyzed the stability of roadway surrounding rock, and put forward the treatment measures for roadway deformation and failure. This kind of research reveals the basic law of mine pressure behavior in the process of short distance coal seam mining, fills in the deficiency of short distance coal seam mining theory, and greatly improves the recovery rate of coal resources. However, there are relatively few research studies on the behavior law of ground pressure in bifurcated coal seam mining, and the transmission law of ground pressure on the floor is not clear. The mining of upper coal seam leads to the change of original rock stress, which tends to a new balance. The overburden migration is the direct embodiment of surrounding rock stress tending to a new balance. Regarding the mining of close coal seam group, the migration law of overburden and the evolution characteristics of stress field have become subject of research, while the research methods vary. FLAC ${ }^{3 \mathrm{D}}, \mathrm{RFPA}^{2 \mathrm{D}}$, UDEC, and other software are widely used in stope simulation [12-15]. Two-dimensional and three-dimensional indoor similar tests can assess the stope conditions reliably reducing the research cost [16-19]. A mechanical model under different geological conditions can better reveal the mechanism of overlying strata migration and fracture in the mining process of close coal seam [20-24]. The above research results provide scientific guidance for the layout of coal seam gas drainage holes, the selection of roof and floor grouting reinforcement drilling position, and the selection of roadway support mode. However, in the mining of bifurcation coal seam, there are few studies on the structural types and evolution characteristics of stope surrounding rock. Especially the evolution characteristics of stope surrounding rock structure in bifurcation coal seam are not clear, requiring further study. The theoretical research results are verified by field measurement, which is a virtuous circle of scientific guidance for production practice. Many scientific and technological means are used for monitoring and investigating the deformation and failure of overlying strata in close distance stope roof and floor [25-32]. A traditional method to survey the height of "two zones" (caving zone and fracture zone) is the simple hydrological observation technology, which is more mature and widely used in field measurement. It mainly includes simple hydrological observation of surface drilling and underground inclined hydrological observation. This paper uses this method to estimate the height of "two zones" of coal seam overburden and the depth of floor damage, providing basis for the classification of the overburden structure. Under the influence of repeated mining in close distance coal seam, the deformation of roadway in lower coal seam is severe. Many scholars have studied the failure mechanism of roadway and put forward the corresponding control technology to ensure safe and efficient mining of working face [33-36]. Some researchers established the relationship between hydraulic support and surrounding rock, through the study of roof and interlayer rock structure in close distance coal seam, revealing the control mechanism of rock structure on stope surrounding rock [37-40]. The research results constituted a theoretical basis for the selection of hydraulic support and parameters. This paper analyzes the structural evolution characteristics of surrounding rock from the perspective of engineering geology, which can provide theoretical guidance for the treatment of roadway and surrounding rock during bifurcation coal seam mining.

Based on the above analysis, scholars have carried out a lot of research work around the stope of close coal seam and have obtained more research results. However, there are few reports on the study of bifurcation coal seam. The transfer law of mine pressure in the floor under the influence of mining is not clear. The structural characteristics of surrounding rock in the stope are relatively few, and the determination of the target area of broken roof governance lacks theoretical support. In this paper, a series of studies have been carried out to encounter the difficulty of controlling the regenerated roof of the lower coal seam in an actual mine project. Through theoretical analysis, field measurement, and indoor similar simulation test, the transmission characteristics of the stope pressure in the floor under the influence of upper coal seam mining are analyzed, and the rock mass structure characteristics of the regenerated roof of the bifurcated close coal seam are assessed. The stability of different types of regenerated roof structure is evaluated so as to provide a scientific basis for the determination of broken roof treatment target area in the lower coal seam. The research results can provide a reference for the treatment of broken roof under similar conditions.

\section{Engineering Geological Background}

Xutuan Coal Mine is located in Xutuan Town, Bozhou City, Anhui Province, in China. No. 7-1 (upper coal seam) and No. 7-2 (lower coal seam) are the main coal seams in the mine, and the spatial form shows a bifurcation merging relationship. This paper studies 71212 and 72210 working faces in 82 mining area. The spacing of coal seam in the mining area is shown in Figure 2, which in the northeast, and southwest of the mining area is relatively small, and near the middle of the mining area gradually becomes larger. Hence, the interlayer thickness gradually increases from the southeast and southwest of the mining area to the middle of the mining area.

The lower part of 71212 working face in 82 mining area is 72210 working face. The spacing of No. 7-1 and No. 7-2 coal seams varies between $0.7 \mathrm{~m}$ and $9.02 \mathrm{~m}$, with an average of 


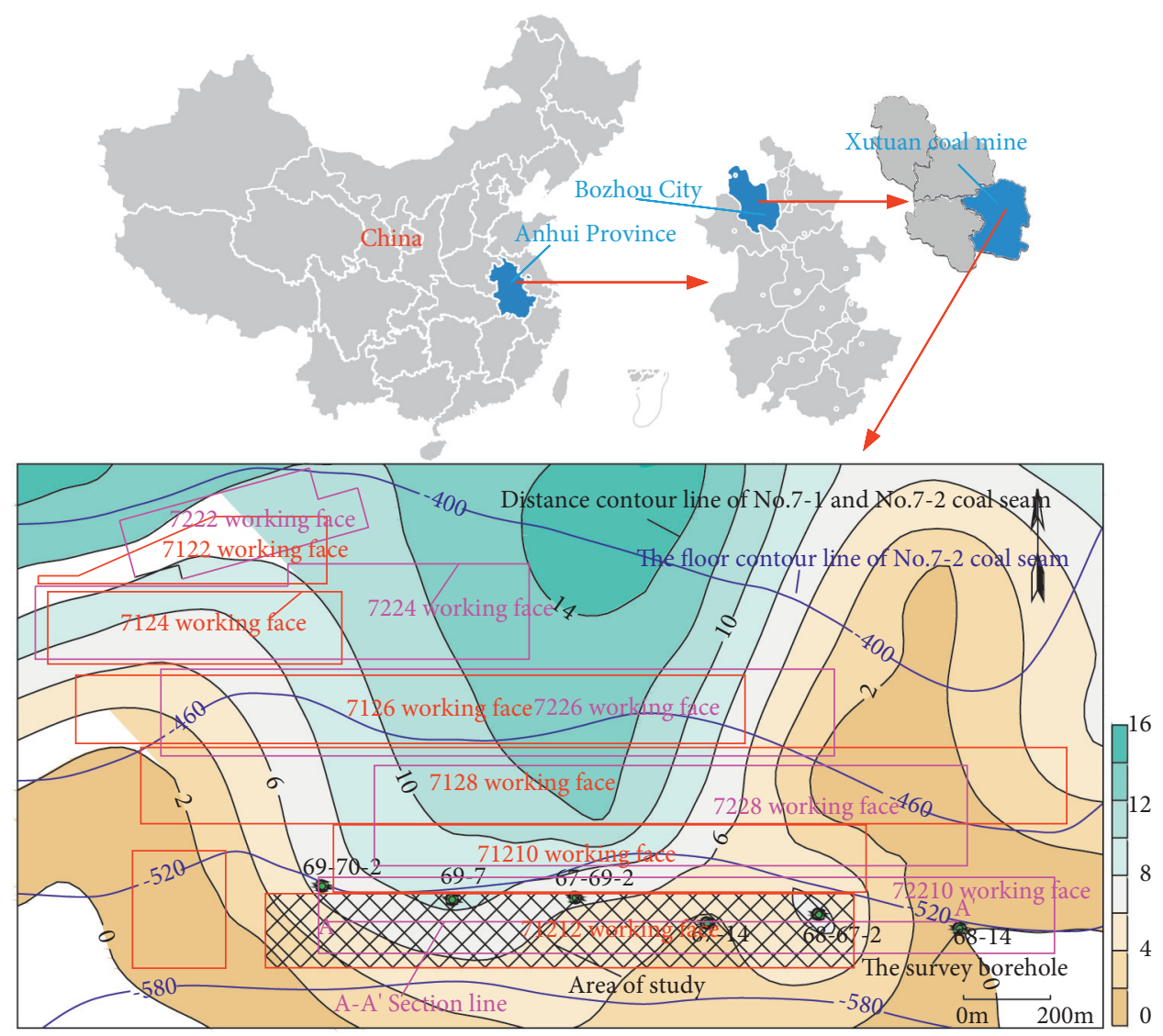

Figure 2: Contour map of No. 7-1 and No. 7-2 coal seam spacing in 82 mining area.

$5.84 \mathrm{~m}$. The strike length of 71212 working face is $1366 \mathrm{~m}$, the inclined width is $170 \mathrm{~m}$, the average thickness of coal seam is $2.8 \mathrm{~m}$, and the dip angle of coal seam is $15^{\circ}$. The strike length of 72210 working face is $2023 \mathrm{~m}$, the inclined width is $190 \mathrm{~m}$, the average thickness of coal seam is $3 \mathrm{~m}$, and the dip angle of coal seam is $12^{\circ}$.

Through drilling and coring of roof and floor rocks in No. 7-1 and No. 7-2 coal seams, the laboratory rock mechanical properties test was carried out. The comprehensive histogram of working face and the test results of mechanical properties of roof and floor rocks are shown in Figure 3.

\section{Theoretical Calculation of Damage Thickness of Roof and Floor Strata after No. 7- 1 Coal Seam Mining}

3.1. Theoretical Calculation of "Two Zones" Height of Overburden. The roof of No. 7-1 coal seam in 71212 working face is medium hard rock. The Ministry of Coal Industry of China has formulated the coal pillar reservation and coal mining regulations for buildings, water bodies, railways, and main roadways (2019 Edition) and put forward the calculation formula for the height of the collapse zone and water flowing fracture zone of medium hard overburden (the average compressive strength of overburden is $20 \mathrm{MPa}-40 \mathrm{MPa}$ ), as shown in formulas (1) and (2) [41].

$$
\begin{aligned}
H_{c} & =\frac{100 \sum M}{4.7 \sum M+19} \pm 2.2, \\
H_{f} & =\frac{100 \sum M}{1.6 \sum M+3.6} \pm 5.6,
\end{aligned}
$$

where $H_{c}$ is the height of the caving zone, $H_{f}$ is the height of the fracture zone, and $\sum M$ is the cumulative mining thickness of coal seam, with the unit of $\mathrm{m}$.

3.2. Theoretical Calculation of Floor Failure Depth. According to the general conclusion of soil mechanics experiment, combined with the actual situation of coal seam floor, it is considered that the slip line (boundary of the plastic failure zone) of limit state of floor rock under abutment pressure is shown in Figure 4. The plastic failure boundary is composed of three zones: I and III are active and passive limit zones, respectively, while II is the transition zone [42-44].

The calculation diagram of the maximum plastic failure depth $h$ is shown in Figure 5 .

The equation for the logarithmic spiral is as follows:

$$
r=r_{0} e^{\theta \tan \phi}
$$

In formula (3), $r$ is the polar radius, $\theta$ is the polar angle, $r_{0}$ is a constant, and the expression of $r_{0}$ is as follows: 


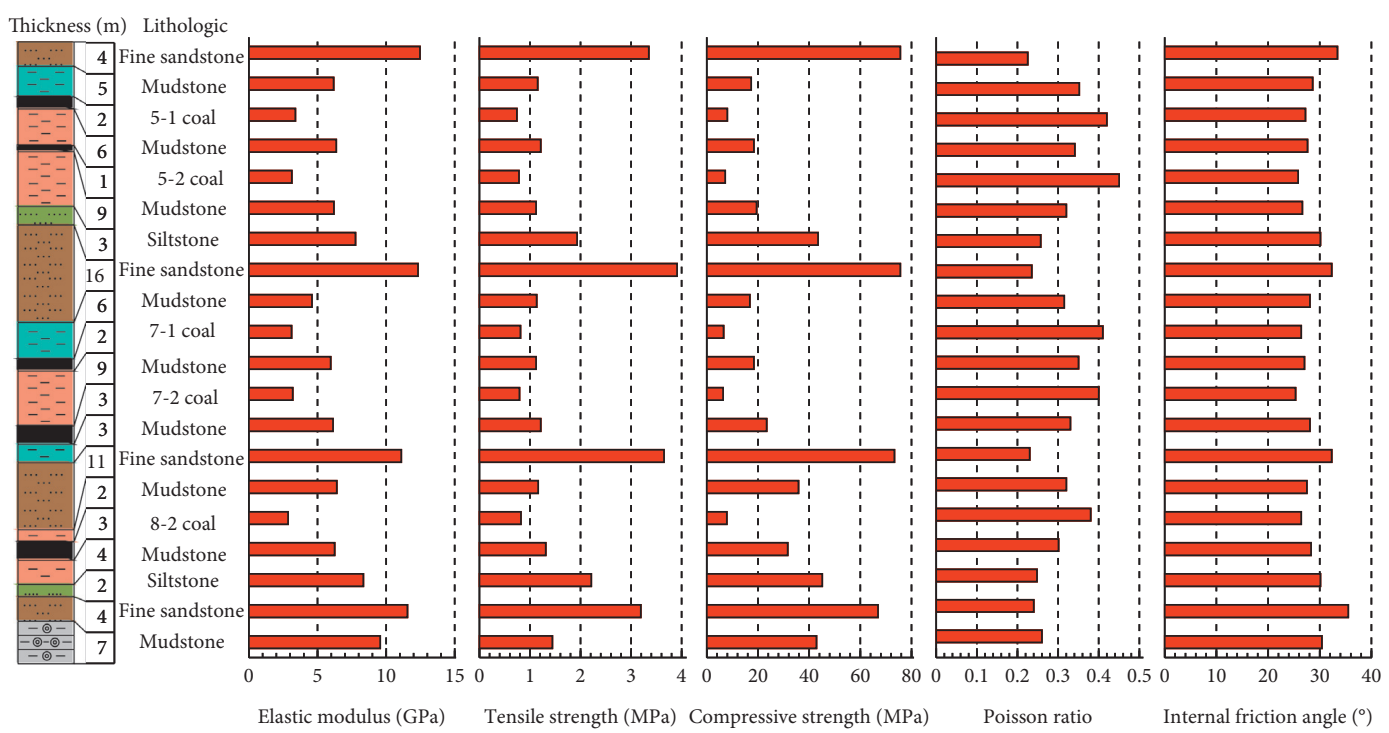

FIgURE 3: Test results of rock mechanical properties.

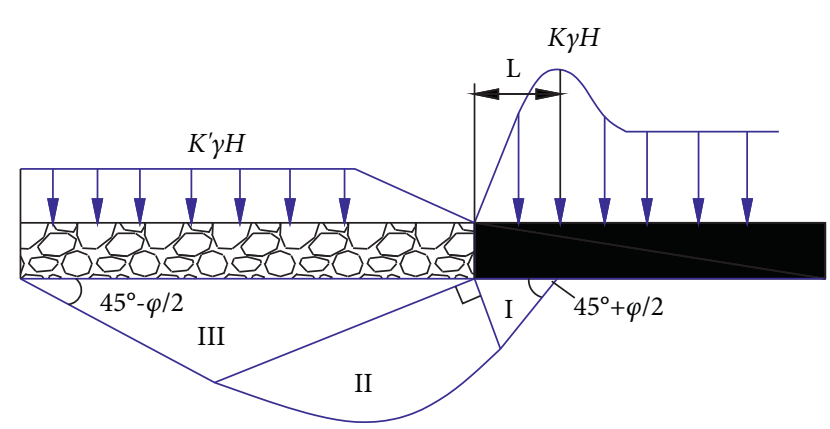

FIGURE 4: Schematic diagram of the plastic failure zone of floor.

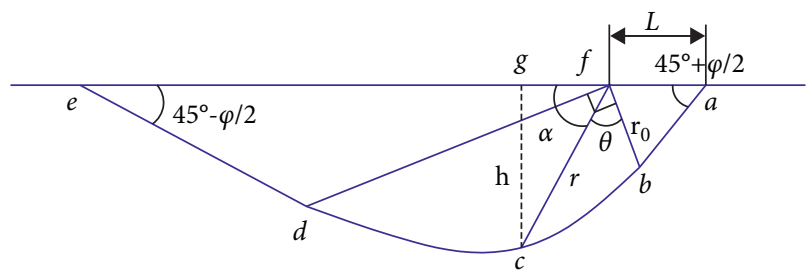

Figure 5: Calculation diagram of plastic zone range of floor.

$$
r_{0}=\frac{L}{2 \cos ((\phi / 2)+(\pi / 4))} .
$$

According to the geometric relationship in Figure 5, the depth $h$ of the plastic failure zone under ultimate bearing pressure can be determined as follows:

$$
\begin{aligned}
& h=r \sin \alpha, \\
& \alpha=\pi-\left(\frac{\phi}{2}+\frac{\pi}{4}\right)-\theta .
\end{aligned}
$$

From $(\mathrm{d} h / \mathrm{d} \theta)=0$, the maximum depth $h_{\max }$ of the failure zone can be obtained:

$$
h_{\max }=\frac{L \cos }{2 \cos ((\phi / 2)+(\pi / 4))} e^{((\phi / 2)+(\pi / 4)) \tan \phi} .
$$

The plastic zone width $L$ of coal pillar in long wall working face can be calculated by the following empirical formula [45]:

$$
L=\frac{M}{2 \xi f} \ln \frac{K \gamma H+C \cot \phi}{\xi\left(p_{x}+C \cot \phi\right)} .
$$

The maximum yield failure depth $h_{\max }$ of floor rock is determined by using formulas (6) and (7), as follows:

$$
h_{\max }=\frac{M \cos \phi \ln \left(K \gamma H+C \cot \phi / \xi\left(p_{x}+C \cot \phi\right)\right)}{4 \xi f \cos ((\phi / 2)+(\pi / 4))} e^{((\phi / 2)+(\pi / 4)) \tan \phi},
$$

where $M$ is the thickness of coal seam, unit: $m ; \varphi$ is the internal friction angle of coal body; $K$ is the stress concentration coefficient; $\gamma$ is the average bulk density of overlying strata in mining field, unit: $\mathrm{MN} / \mathrm{m}^{3} ; \mathrm{H}$ is the buried depth of coal seam, unit: $\mathrm{m}$; $C$ is the cohesion of coal, unit: $\mathrm{MPa} ; p_{x}$ is the resistance of the support to the coal side, unit: $\mathrm{KN}$; $f$ is the friction coefficient of the interface between coal seam and roof and floor; $L$ is the width of the plastic zone of coal pillar, unit: $\mathrm{m}$; and $\xi$ is triaxial stress coefficient, $\xi=(1+\sin \phi / 1-\sin \phi)$.

3.3. Case Analysis. According to the survey drilling information of 71212 working face in Xutuan Coal Mine, using formulas (1), (2), and (8), the height of the caving zone and fracture zone, the depth of the failure zone of floor, and the width of the plastic zone of coal pillar in 71212 working face are calculated, respectively. The calculation results are shown in Table 1.

Based on the data of Table 1, the evolution diagram of surrounding rock structure after mining of No. 7-1 coal seam is drawn, as shown in Figure 6. 
TABLE 1: Theoretical calculation results of roof and floor strata mining damage thickness.

\begin{tabular}{|c|c|c|c|c|c|}
\hline Borehole number & $M(\mathrm{~m})$ & $H_{c}(\mathrm{~m})$ & $H_{f}(\mathrm{~m})$ & $L(\mathrm{~m})$ & $h_{\max }(\mathrm{m})$ \\
\hline $69-70-2$ & 2.80 & 8.71 & 34.65 & 3.96 & 6.28 \\
\hline $69-7$ & 2.80 & 8.71 & 34.65 & 3.97 & 6.29 \\
\hline $67-69-2$ & 2.80 & 8.71 & 34.65 & 3.99 & 6.33 \\
\hline $67-14$ & 2.80 & 8.71 & 34.65 & 4.04 & 6.40 \\
\hline $68-67-2$ & 2.80 & 8.71 & 34.65 & 4.00 & 6.33 \\
\hline $68-14$ & 2.80 & 8.71 & 34.65 & 4.00 & 6.34 \\
\hline
\end{tabular}

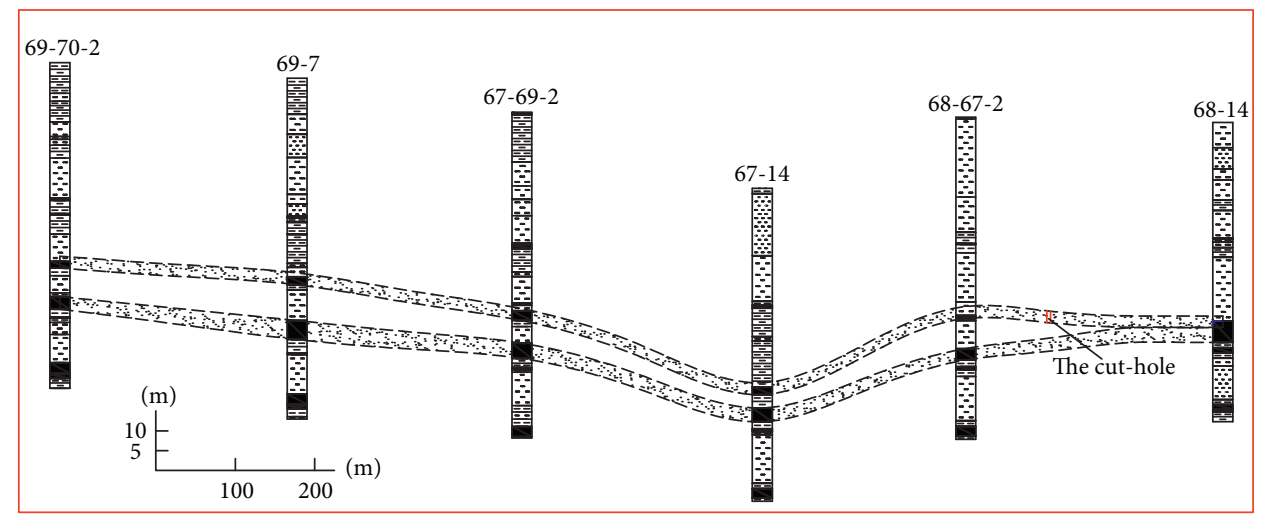

(a)

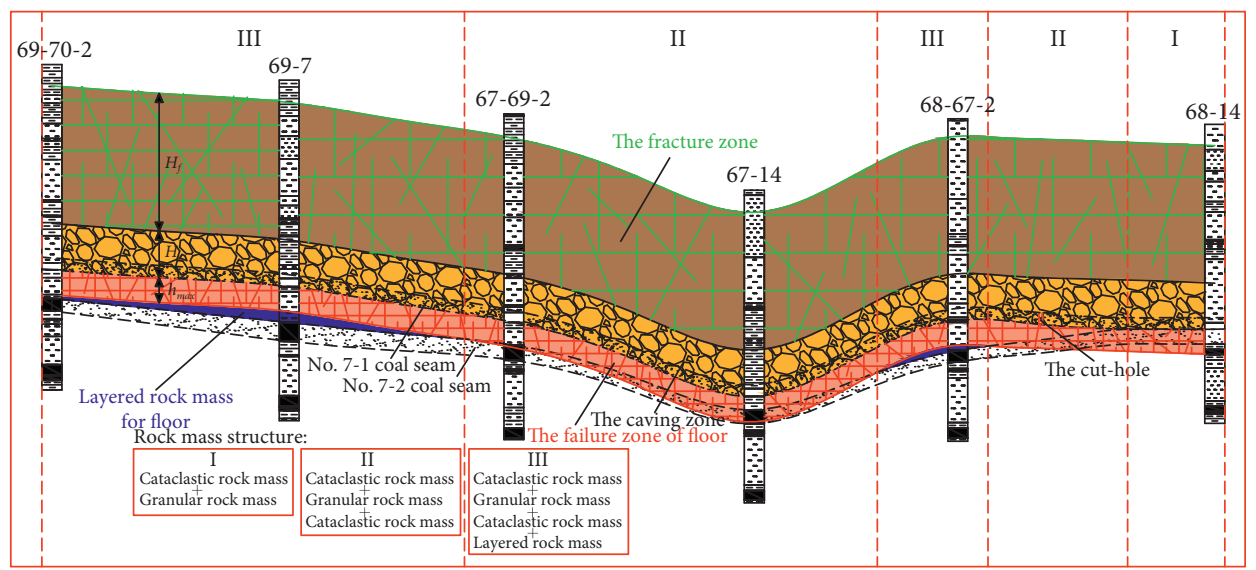

(b)

Figure 6: Schematic diagram of surrounding rock structure of No. 7-1 coal seam stope: (a) original strata diagram; (b) schematic diagram of rock mass structure after mining in No. 7-1 coal seam.

It can be noted that after the mining of No. 7-1 coal seam, the surrounding rock migrates and forms the caving zone, fracture zone, and strong floor failure zone. The rock mass in the fracture zone, which belongs to cataclastic rock mass structure, is cracked, and its integrity is destroyed. The one in the caving zone is loose, and it belongs to granular rock mass structure. Due to the severe influence of the stope pressure, the rock mass in the strong failure zone of the floor is partially broken and belongs to the cataclastic rock mass structure. The one in the lower part of the strong failure zone of the floor is less affected by the mining procedure. Therefore, it can be considered to be in the original state, characterized as layered rock structure. Due to the difference of coal seam spacing, the roof of No. 7-2 coal seam can be divided into different rock mass structure combination types from top to bottom in the study area after mining No. 7-1 coal seam, which are I: cataclastic rock mass + granular rock mass; II: cataclastic rock mass + granular rock mass + cataclastic rock mass; and III: cataclastic rock mass + granular rock mass + cataclastic rock mass + layered rock mass. Based on Table 1, the average thickness of the floor failure zone is $6.33 \mathrm{~m}$. When the coal seam spacing is larger than $6.33 \mathrm{~m}$, a layered rock mass is created in the floor of No. 7-1, which controls the movement of the overlying strata. Based on the composition of the rock mass structure, the stability of the roof structure is as follows: III $>$ II $>$ I.

\section{Field Measurement of Roof and Floor Rock Failure Range}

Simple hydrogeological observation of borehole is the observation and record of water level and temperature in 
borehole, consumption of flushing fluid, and water inflow in drilling engineering. According to the consumption of drilling flushing fluid, the change of water inflow, and its change rate, combined with the observation data of dynamic change of water level in the hole, geological data and the evolution of "air leakage," and "drill dropping and sticking" phenomena during the drilling process, the fracture development degree of the rock stratum is mastered, and the height of "two zones" of overlying strata and the damage depth of floor are determined [46].

Seven ground survey boreholes were conducted in 71212 working face of Xutuan Coal Mine, numbered $\mathrm{X}_{1}, \mathrm{X}_{2}, \mathrm{X}_{3}, \mathrm{X}_{4}$, $\mathrm{X}_{5}, \mathrm{X}_{6}$, and $\mathrm{X}_{7}$, respectively. The borehole is drilled from the earth's surface to No.7-2 coal seam. The position of the boreholes in plan-view and the distance between them are shown in Figure 7. The height of the "two zones" and the damage depth of the floor are measured by simple hydrological observation during the drilling of the exploratory hole. The survey boreholes can be used as a ground grouting holes for grouting reinforcement of No. 7-2 coal roof, and all boreholes were reopened for use as gas drainage boreholes to achieve multipurpose.

According to the simple hydrological observation onsite, the monitoring data of borehole flushing fluid consumption within $80 \mathrm{~m}$ above the top of No. 7-2 coal seam are extracted, and the variation curves of borehole flushing fluid consumption are drawn in Figure 8.

It can be noted that the overlying strata migration of roof is affected by the mining of No. 7-1 coal seam, forming caving and fracture zones, and the consumption of drilling flushing fluid varies in different regions. When drilling in the fracture zone, the consumption of flushing fluid in the hole increases and the water level decreases. When drilling in the caving zone, the rock stratum in this area presents a granular form. Pores and fractures are developed. The flushing fluid in the hole is fully consumed, and the water level in the hole is 0 . During the drilling process, the phenomena of "air leakage" and "lost drilling and stuck drilling" occur. Due to the influence of stope pressure, strong and weak failure zones are formed at the floor of the upper coal seam. When drilling in the floor of No. 7-1 coal seam, the consumption of flushing fluid in the strong failure zone is larger than that in the fracture zone and smaller than that in the caving zone. The flushing fluid consumption in the weak failure zone is small, slightly larger than that in the intact rock zone, and the rock integrity of this zone is basically close to the original layered strata. According to the consumption of flushing fluid, the caving zone, fracture zone, strong failure zone of floor, and weak failure zone of floor are divided, as shown in Figure 8, and their thicknesses are listed in Table 2.

Based on Figure 8 and Table 2, the measured depth of the strong failure zone varies between $4.20 \mathrm{~m}$ and $6.55 \mathrm{~m}$. When the coal seam spacing is smaller than $5.78 \mathrm{~m}$, the rock stratum of the No. 7-1 coal seam floor is completely destroyed creating the strong failure zone, and no weak failure zone is formed. When the coal seam spacing is larger than $5.78 \mathrm{~m}$, there is a weak failure zone at the No. 7-1 coal seam floor, and the mechanical properties of the rock stratum in this region are close to the complete layered rock stratum. In this case, the average depth of the failure zone of the No. 7-1 coal seam floor is $6.22 \mathrm{~m}$, which is close to the theoretical calculation value of $6.33 \mathrm{~m}$. The average height of the measured caving zone and fracture zone is $7.95 \mathrm{~m}$ and $34.82 \mathrm{~m}$, which are close to the theoretical calculation values of $8.71 \mathrm{~m}$ and $34.65 \mathrm{~m}$. Based on the above survey, the following conclusions can be drawn: from the middle of the working face to the cut-hole and stop mining line, the measured thickness of the caving and fracture zones increases gradually. This indicates that with the advance of the working face, the permeability coefficient decreases after the middle of the goaf, which is compacted. Due to the support of cantilever beam at the coal wall around the goaf, the degree of compaction is poor and the permeability is larger. This reveals the control mechanism of the compaction of broken rock in the goaf on its permeability. The theoretical calculation value is corrected according to the measured ones at different positions of the working face. This methodology can provide the basis for the accurate calculation of the height of the caving and fracture zones in the bifurcation coal seam mining under similar conditions in the mining area, reducing thus the cost of boreholes investigation.

\section{Similar Simulation Test Study on Downward Mining of Bifurcation Coal Seam}

Due to the complex geological environment of the working face, it is difficult to carry out the field test as the cost is high. Based on the similarity theory, the geological conditions of the prototype working face are converted to the ones of a model to carry out an indoor similarity simulation test. This approach has become an important research method $[47,48]$.

5.1. Determination of Similar Simulation Material Parameters. According to the similarity principle, the similarity ratios between the original rock (prototype) and the model for all the necessary geometric and mechanical characteristics are given in Table 3 . Combined with the mechanical test results of the roof and floor rock mass of the working face, the mechanical strength and material ratio can be determined. The detailed parameters are listed in Table 4.

5.2. Construction of Similar Simulation Model. The similar model consists of two main systems: frame system and test system. As shown in Figure 9, the size of the frame system is $300 \mathrm{~cm} \times 30 \mathrm{~cm} \times 200 \mathrm{~cm}$ (length $\times$ width $\times$ height), and the test system mainly includes the displacement and stress monitoring system. According to the geological conditions of 71212 and 72210 working faces, the coal seam in the bifurcation section was selected as the prototype of this model design. The angle between the upper and lower coal seams was $5^{\circ}$, and the distance between the coal seams in the excavation section ranged from $0 \mathrm{~cm}$ to $19.25 \mathrm{~cm}$. The excavation size of the model design was $220 \mathrm{~cm}$, and the height and width of the model were 


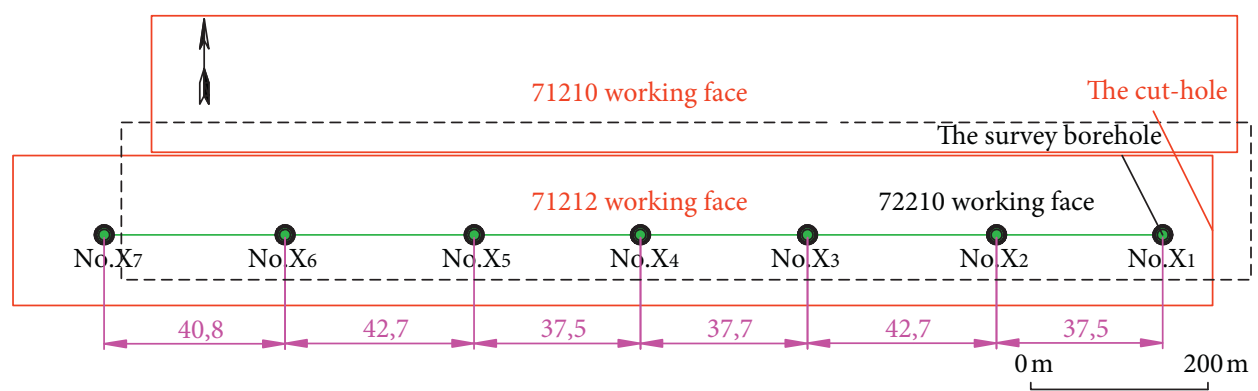

Figure 7: Position diagram of survey boreholes.

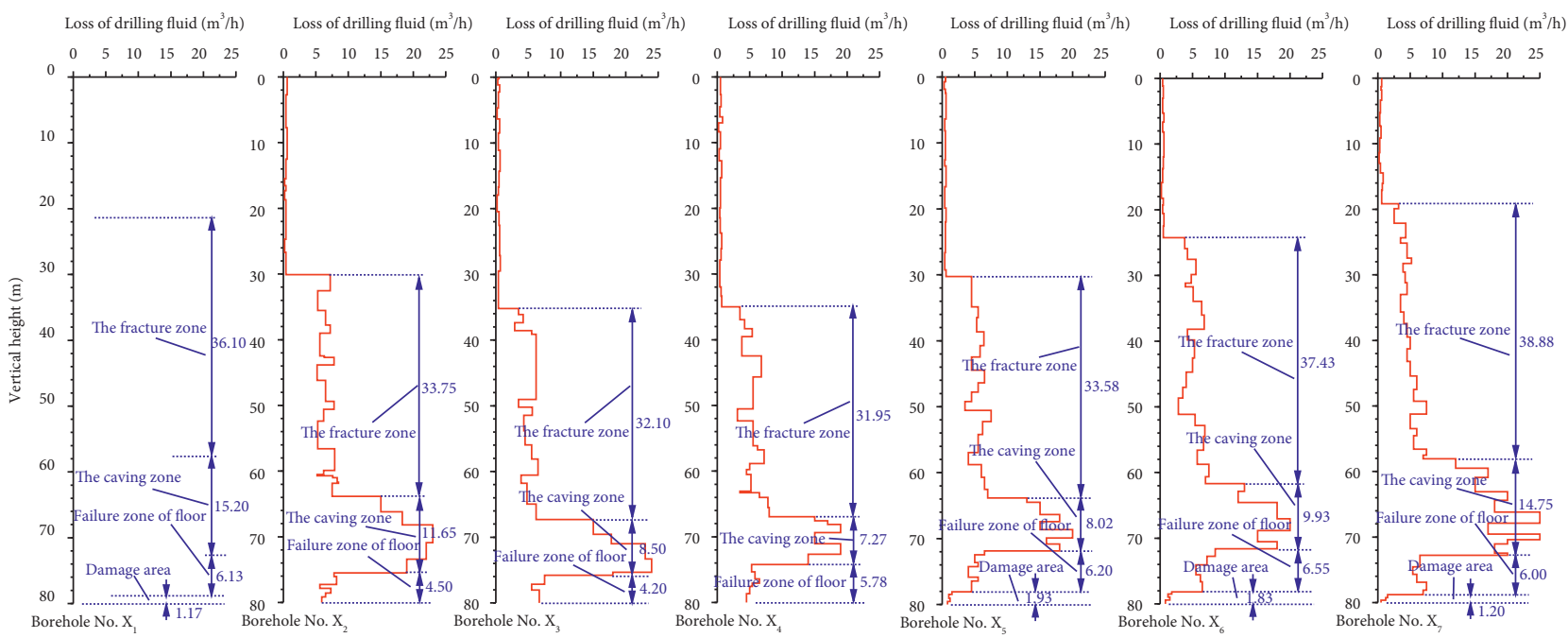

FIgURe 8: Consumption curves of drilling fluid.

TABle 2: Measured height of each zone in stope.

\begin{tabular}{|c|c|c|c|c|c|}
\hline $\begin{array}{l}\text { Borehole } \\
\text { number }\end{array}$ & $\begin{array}{c}\text { Distance between coal } \\
\text { seams }(\mathrm{m})\end{array}$ & $\begin{array}{l}\text { Thickness of floor } \\
\text { damage zone }(\mathrm{m})\end{array}$ & $\begin{array}{l}\text { Thickness of failure zone } \\
\text { for floor }(\mathrm{m})\end{array}$ & $\begin{array}{c}\text { Height of caving } \\
\text { zone }(\mathrm{m})\end{array}$ & $\begin{array}{c}\text { Height of fracture } \\
\text { zone }(\mathrm{m})\end{array}$ \\
\hline No. $X_{1}$ & 7.30 & 1.17 & 6.13 & 12.40 & 36.10 \\
\hline No. $\mathrm{X}_{2}$ & 4.50 & - & 4.50 & 8.85 & 33.75 \\
\hline No. $X_{3}$ & 4.20 & - & 4.20 & 5.70 & 32.10 \\
\hline No. $\mathrm{X}_{4}$ & 5.78 & - & 5.78 & 4.47 & 31.95 \\
\hline No. $X_{5}$ & 8.13 & 1.93 & 6.20 & 5.22 & 33.58 \\
\hline No. $\mathrm{X}_{6}$ & 8.38 & 1.83 & 6.55 & 7.06 & 37.43 \\
\hline No. $X_{7}$ & 7.20 & 1.20 & 6.00 & 11.95 & 38.88 \\
\hline
\end{tabular}

TABLE 3: Main constants for similar simulation experiment.

\begin{tabular}{lcc}
\hline Similarity constant & Model & Original rock \\
\hline Similarity ratio of geometric & 1 & 100 \\
Similarity ratio of bulk density & 0.608 & 1 \\
Similarity ratio of elastic modulus & 0.00608 & 1 \\
Similarity ratio of strength & 0.00608 & 1 \\
Similarity ratio of Poisson & 1 & 1 \\
Similarity ratio of time & 1 & 10 \\
\hline
\end{tabular}

$150 \mathrm{~cm}$ and $30 \mathrm{~cm}$, respectively. The boundary coal pillars on both sides of the model were $40 \mathrm{~cm}$ to eliminate the influence of the boundary effect.

The model materials are shown in Figure 10, mainly including river sand, lime, gypsum, mica, and water.
5.3. Analysis of Similar Simulation Results. During the mining of No. 7-1 and No. 7-2 coal seams, the deformation and failure of the surrounding rock of the stope are monitored throughout the whole process. The monitoring results are shown in Figures 11 and 12.

As shown in Figure 11(a), when the No. 7-1 coal seam mining is carried out in the first $30 \mathrm{~m}$, the roof collapses and microcracks begin to develop. When advancing to $110 \mathrm{~m}$, the main roof experiences four periodic faults. The division of the caving zone and fracture zone is shown in Figure 11(b). The development height of the caving zone is $8 \mathrm{~m}$, and the one of the fracture zone is $17 \mathrm{~m}$. The rock stratum at the head of the working face forms a cantilever beam structure [49]. After completing the mining of No. 7-1 coal seam, as shown in Figure 11(c), the height of the caving zone is maintained at 
TABLE 4: Material parameters and mixing ratios.

\begin{tabular}{|c|c|c|c|c|c|c|c|c|}
\hline & Original rock & & & Model & & & & \\
\hline & & & & Material 1 & & Weigh & ht of mate & rial (kg) \\
\hline Lithology & $(\mathrm{m})$ & $(\mathrm{MPa})$ & $(\mathrm{MPa})$ & $\begin{array}{l}\text { Sand : lime: } \\
\text { gypsum }\end{array}$ & Sand & Lime & Gypsum & Water \\
\hline Mudstone & 2.0 & 20.40 & 0.124 & $12: 3: 7$ & 27.9 & 0.7 & 1.6 & 3.0 \\
\hline Siltstone & 4.0 & 43.44 & 0.264 & $10: 7: 3$ & 55.0 & 3.8 & 1.6 & 6.0 \\
\hline Mudstone & 1.0 & 18.50 & 0.112 & $12: 3: 7$ & 14.0 & 0.3 & 0.8 & 1.5 \\
\hline Fine sandstone & 2.0 & 52.80 & 0.460 & $8: 7: 3$ & 26.9 & 2.4 & 1.0 & 3.0 \\
\hline Mudstone & 2.0 & 18.40 & 0.112 & $12: 3: 7$ & 27.9 & 0.7 & 1.6 & 3.0 \\
\hline Siltstone & 2.0 & 41.70 & 0.264 & $10: 7: 3$ & 27.5 & 1.9 & 0.8 & 3.0 \\
\hline Mudstone & 3.0 & 17.30 & 0.112 & $12: 3: 7$ & 41.9 & 1.0 & 2.4 & 4.5 \\
\hline Fine sandstone & 4.0 & 71.80 & 0.460 & $8: 7: 3$ & 53.8 & 4.7 & 2.0 & 6.0 \\
\hline Siltstone & 2.0 & 35.70 & 0.264 & $10: 7: 3$ & 27.5 & 1.9 & 0.8 & 3.0 \\
\hline Mudstone & 9.0 & 20.50 & 0.112 & $12: 3: 7$ & 125.6 & 3.1 & 7.3 & 13.6 \\
\hline Fine sandstone & 4.0 & 65.00 & 0.460 & $8: 7: 3$ & 53.8 & 4.7 & 2.0 & 6.0 \\
\hline Mudstone & 5.0 & 19.20 & 0.112 & $12: 3: 7$ & 69.8 & 1.7 & 4.1 & 7.6 \\
\hline $\begin{array}{l}\text { No. 5-1 coal } \\
\text { seam }\end{array}$ & 2.0 & 6.50 & 0.038 & $13: 4: 6$ & 28.1 & 0.9 & 1.3 & 3.0 \\
\hline Mudstone & 6.0 & 17.50 & 0.112 & $12: 3: 7$ & 83.7 & 2.1 & 4.9 & 9.1 \\
\hline $\begin{array}{l}\text { No. 5-2 coal } \\
\text { seam }\end{array}$ & 1.0 & 7.30 & 0.038 & $13: 4: 6$ & 14.0 & 0.4 & 0.6 & 1.5 \\
\hline Mudstone & 9.0 & 18.30 & 0.112 & $12: 3: 7$ & 125.6 & 3.1 & 7.3 & 13.6 \\
\hline Siltstone & 3.0 & 29.50 & 0.264 & $10: 7: 3$ & 41.2 & 2.9 & 1.2 & 4.5 \\
\hline Fine sandstone & 1.0 & 55.80 & 0.460 & $8: 7: 3$ & 13.4 & 1.2 & 0.5 & 1.5 \\
\hline Mudstone & 3.0 & 19.40 & 0.112 & $12: 3: 7$ & 41.9 & 1.0 & 2.4 & 4.5 \\
\hline Fine sandstone & 16.0 & 76.50 & 0.460 & $8: 7: 3$ & 215.0 & 18.8 & 8.1 & 24.2 \\
\hline Siltstone & 11.0 & 45.90 & 0.264 & $10: 7: 3$ & 151.2 & 10.6 & 4.5 & 16.6 \\
\hline Mudstone & 6.0 & 15.50 & 0.112 & $12: 3: 7$ & 83.7 & 2.1 & 4.9 & 9.1 \\
\hline Fine sandstone & 5.0 & 60.30 & 0.460 & $8: 7: 3$ & 67.2 & 5.9 & 2.5 & 7.6 \\
\hline Mudstone & 5.0 & 16.80 & 0.112 & $12: 3: 7$ & 69.8 & 1.7 & 4.1 & 7.6 \\
\hline $\begin{array}{l}\text { No. } 7-1 \text { coal } \\
\text { seam }\end{array}$ & 2.0 & 8.20 & 0.038 & $13: 4: 6$ & 28.1 & 0.9 & 1.3 & 3.0 \\
\hline Mudstone & $0 \sim 23$ & 18.40 & 0.112 & $12: 3: 7$ & 137.6 & 3.4 & 8.0 & 14.9 \\
\hline $\begin{array}{l}\text { No. } 7-2 \text { coal } \\
\text { seam }\end{array}$ & 3.0 & 7.50 & 0.038 & $13: 4: 6$ & 42.2 & 1.3 & 1.9 & 4.5 \\
\hline Mudstone & 3.0 & 23.36 & 0.142 & $12: 3: 7$ & 38.9 & 1.0 & 2.3 & 4.2 \\
\hline Fine sandstone & 11.0 & 75.60 & 0.460 & $8: 7: 3$ & 148.4 & 13.0 & 5.6 & 16.7 \\
\hline Mudstone & 2.0 & 45.07 & 0.274 & $10: 7: 3$ & 26.7 & 1.9 & 0.8 & 2.9 \\
\hline $\begin{array}{l}\text { No. } 8-2 \text { coal } \\
\text { seam }\end{array}$ & 3.0 & 8.60 & 0.407 & $8: 7: 3$ & 35.3 & 3.1 & 1.3 & 4.0 \\
\hline Mudstone & 4.0 & 28.50 & 0.192 & $12: 3: 7$ & 41.1 & 1.1 & 2.6 & 4.5 \\
\hline Siltstone & 2.0 & 39.70 & 0.274 & $10: 7: 3$ & 17.2 & 1.2 & 0.5 & 1.9 \\
\hline Fine sandstone & 4.0 & 66.80 & 0.407 & $8: 7: 3$ & 27.5 & 2.4 & 1.0 & 3.1 \\
\hline Mudstone & 4.0 & 31.57 & 0.192 & $12: 3: 7$ & 20.0 & 0.5 & 1.2 & 2.2 \\
\hline
\end{tabular}

$8 \mathrm{~m}$ and the height of the fracture zone is developed to $37 \mathrm{~m}$. The strata in the fracture zone are squeezed and hinged creating masonry beams. The cantilever beam structure formed by the strata at the end of the mining line breaks with the migration of the overlying strata. The rock breaking angles at the cut-hole and stopping line are $54^{\circ}$ and $49^{\circ}$, respectively. After the cantilever beam at the cut-hole and stop mining line breaks, it supports the overlying strata and the porosity is larger than that in the middle of the working face. The closer to the middle of the working face, the larger the degree of rock compaction is and the smaller the porosity is, which are consistent with the development law of the height of the "two zones" measured in the field.

It can be seen from Figure 12 that when the No. 7-2 coal seam advances to $30 \mathrm{~m}$, after the completion of the No. 7-1 coal seam mining, the interlayer rock is completely broken and cannot support the overlying rock. The fracture length of the damaged basic roof decreases with the increase in the damage amount. When the coal seam spacing is larger than $6 \mathrm{~m}$, a layered rock stratum is created at the floor of No. 7-1, and the strength of the cantilever beam increases, supporting the overlying strata. After the cantilever beam breaks, the rock blocks are hinged forming a masonry beam [50], which has a good control effect on the movement of the overlying strata in the stope and verifies the conclusion that type III roof is more stable than types II and I.

During the similar simulation test, it is difficult to observe the microfracture development inside the model. Hence, the stress of the floor of No. 7-1 coal seam is monitored during the mining of No. 7-1 coal seam. By 


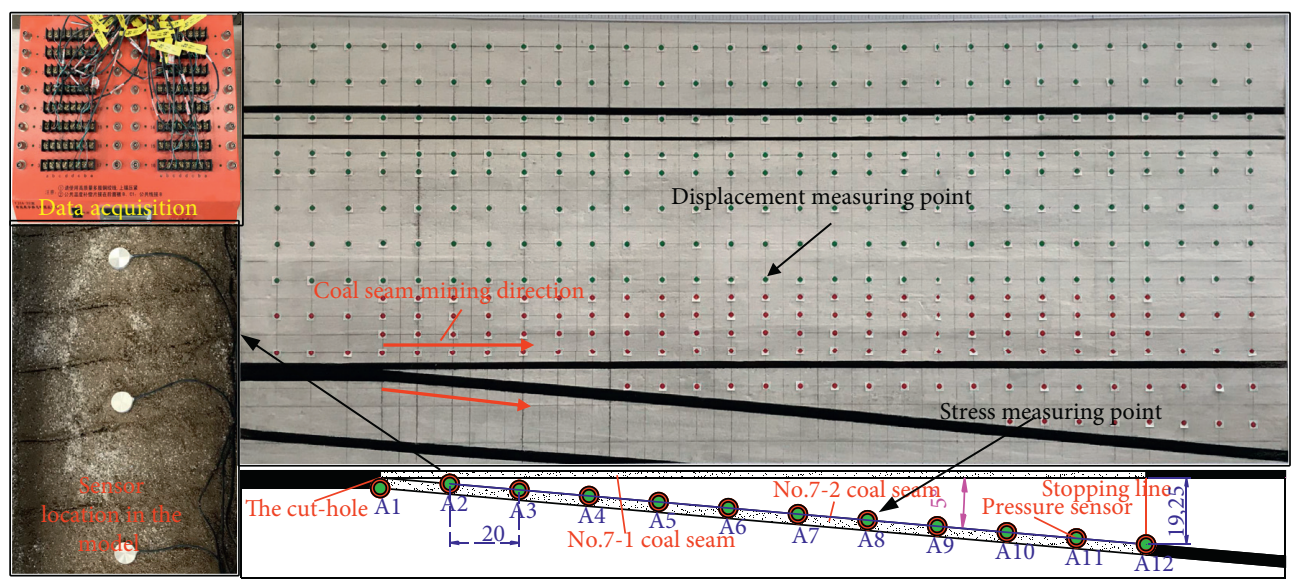

(a)
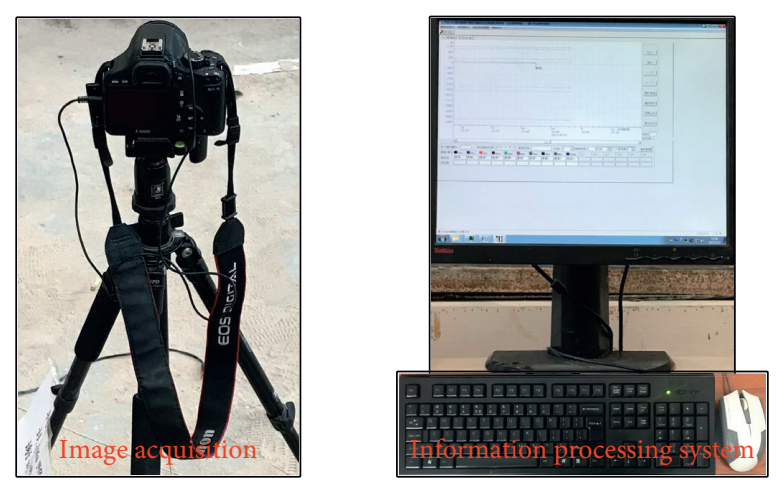

(b)

FIgURE 9: Composition of the similar simulation test system. (a) Frame system. (b) Displacement monitoring system.

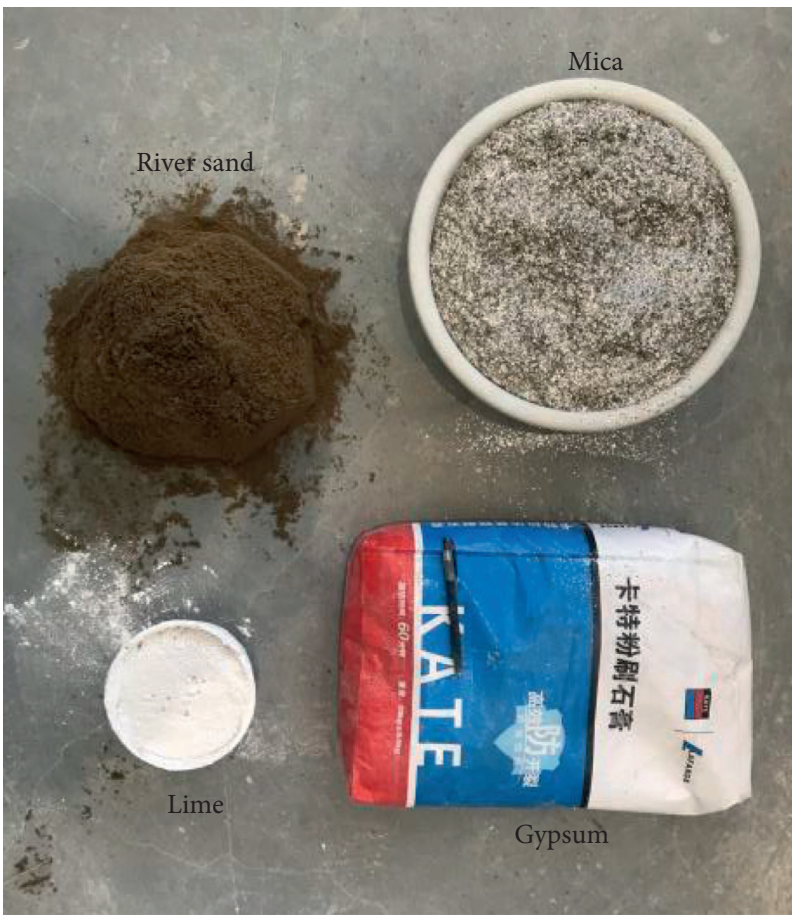

FIgURE 10: Schematic diagram of raw materials for the similar simulation test. 


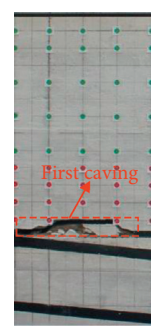

(a)

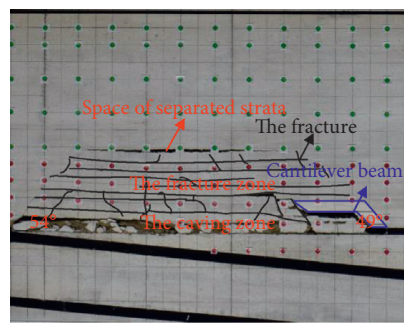

(b)

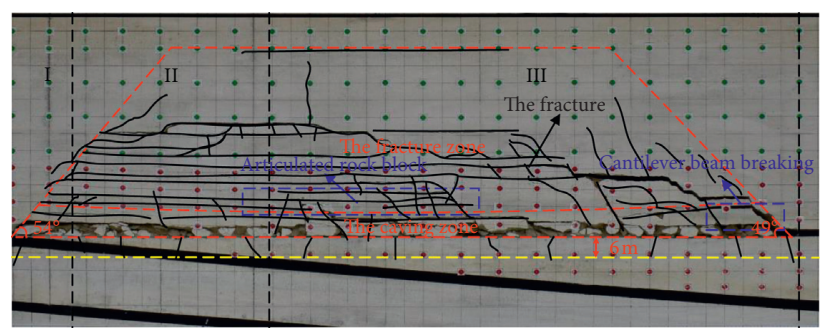

(c)

FIGURE 11: Deformation characteristics of overburden with different advancing distances in the process of No. 7-1 coal seam mining: (a) advancing to $30 \mathrm{~m}$; (b) advancing to $110 \mathrm{~m}$; (c) advancing to $220 \mathrm{~m}$.

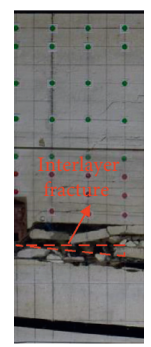

(a)

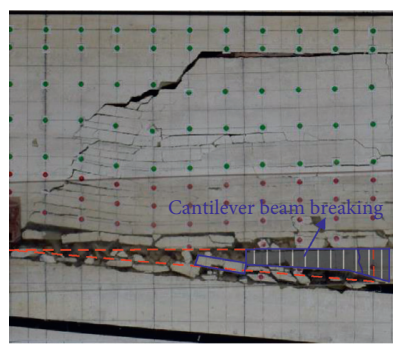

(b)

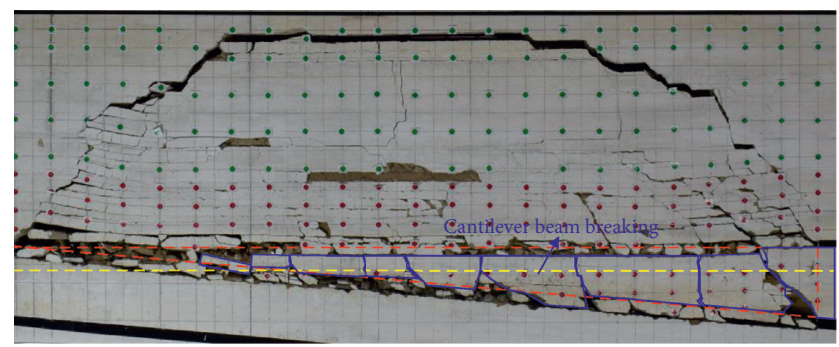

(c)

FIGURE 12: Deformation characteristics of overburden with different advancing distances in the process of No. 7-2 coal seam mining: (a) advancing to $30 \mathrm{~m}$; (b) advancing to $110 \mathrm{~m}$; (c) advancing to $220 \mathrm{~m}$.

analyzing the influence depth of ground pressure on the floor, the failure depth of the floor of No. 7-1 coal seam is indirectly reflected. The sensor stress monitoring data are shown in Figure 13.

The stress change in the floor of No. 7-1, caused by the mining of this upper coal seam, shows regularity. With the increase in burial depth, the stress change trend of A2-A5 stress sensors gradually tends to be uniform. The stress monitoring value of A6-A12 sensors is basically close to the initial stress $(2.8 \mathrm{kPa})$. The distance between $\mathrm{A} 2-\mathrm{A} 5$ sensors and No. 7-1 coal seam varies between $0 \mathrm{~m}$ and $7.00 \mathrm{~m}$, and the distance between A4 sensor and No. 7-1 coal seam is $5.25 \mathrm{~m}$. The influence depth of stress change caused by mining on the floor is $5.25 \mathrm{~m}-7.00 \mathrm{~m}$. The strata in this range are affected by mine pressure. Microfractures are developed, and the strata are destroyed, which is consistent with the theoretical calculation and the measured failure depth of the floor. As shown in Figure 13, with the advance of the working face, the stress of the floor of the mined-out area behind the working face experiences the process from pressurization to pressure relief and then pressurization. When the mined-out area was just formed, the pressure relief degree of floor rock was high. With the periodic collapse and compaction of rock strata, the floor stress began to gradually increase, but it was always slightly smaller than the initial stress, and the stress recovery distance was about $80 \mathrm{~m}$. In the horizontal direction, the advance influence range of abutment pressure is $20 \mathrm{~m}-30 \mathrm{~m}$, and the peak position of abutment pressure is about $5 \mathrm{~m}$ in front of the work.

\section{Discussion}

Based on the above research, it can be found that the thickness and lithology of the interlayer strata play a controlling role in the overlying strata movement of the roof of the lower coal seam during the downward mining of the close coal seam. When the floor failure depth of the upper coal seam after mining is larger than that of the coal seam spacing (I, II), the roof of the lower coal seam is severely cracked. If the roof is not treated, it is difficult to be managed, and roof collapse incidents are prone to occur. When the failure depth of the floor is smaller than the coal seam spacing (III), there is a layered structure of rock in the floor. The cantilever beam structure formed by the interlayer rock layer has a supporting effect on the upper rock layer. Taking certain supporting measures, the lower coal seam can be successfully mined.

This study can provide a theoretical basis for determining the target area of broken roof control in bifurcation coal seam mining under similar conditions. The field measurement and similar simulation test show that the cantilever beam fracture at the cut-hole and stopping line of the working face supports the overlying strata, and the porosity is larger than that in the middle of the working face. The closer to the middle of the working face, the higher the degree of rock compaction is and the smaller the porosity is. This rule can be used to carry out targeted grouting reinforcement at different positions of the roof, providing a reference for the selection of grouting parameters. 


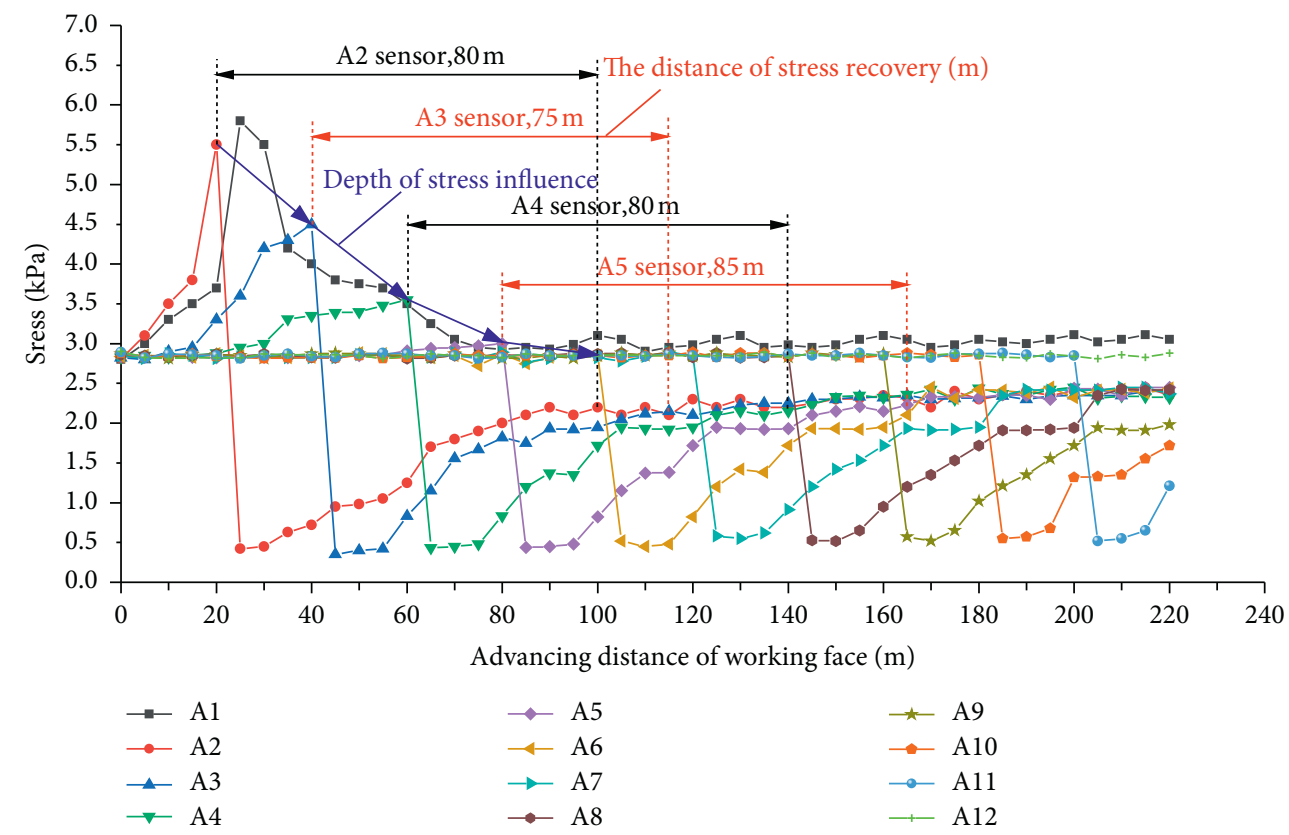

Figure 13: Transfer characteristics of floor stress in mining process of No. 7-1 coal seam.

\section{Conclusion}

A series of mining problems faced by bifurcation coal seam mining have become a research hotspot in recent years. Taking the bifurcation coal seam of Xutuan Coal Mine in China as an example, this paper comprehensively studies the structural evolution characteristics of the regenerated roof of the lower coal seam (No. 7-2) under the influence of the upper coal seam mining (No. 7-1). The main conclusions are as follows:

(1) The theoretical calculation results show that the height of the roof caving zone is $8.71 \mathrm{~m}$, the height of the fracture zone is $34.65 \mathrm{~m}$, and the average depth of the floor failure zone is $6.33 \mathrm{~m}$ after mining in No. 71 coal seam.

(2) The average height of the measured caving zone and fracture zone is $7.95 \mathrm{~m}$ and 34.82, which are basically close to the theoretical calculation values of $8.71 \mathrm{~m}$ and $34.65 \mathrm{~m}$, respectively. The average depth of the No. 7-1 coal seam floor failure zone is $6.22 \mathrm{~m}$, which is close to the theoretical calculation value of $6.33 \mathrm{~m}$.

(3) Similar simulation test results show that the average height of the roof caving zone and fracture zone in No. 7-1 coal seam is $8 \mathrm{~m}$ and $37 \mathrm{~m}$, respectively. The porosity at the cut-hole and stopping line is larger than that in the middle of the working face. The closer to the middle of the working face, the higher the degree of rock compaction and the smaller the porosity. The depth of the strong failure zone of the floor is $5.25 \mathrm{~m}-7 \mathrm{~m}$, which is basically consistent with the theoretical calculation and field measurement. The stress recovery distance of mined-out area and overlying strata is about $80 \mathrm{~m}$.
(4) Combined with the research results of theoretical calculation, field measurement, and indoor similar simulation test, under the influence of mining in No. 7-1 coal seam, the rock mass structure of regenerated roof in No. 7-2 coal seam is classified. When the floor failure depth is larger than the coal seam spacing, it is mainly divided into two types: fractured rock mass + scattered rock mass (I) and fractured rock mass + scattered rock mass + fractured rock mass (II). When the floor failure depth is smaller than the coal seam spacing, the rock mass structure is as follows: fractured rock mass + bulk rock mass + fractured rock mass + layered rock mass (III). The structural stability of three types of regenerated roof is as follows: III $>$ II $>$ I.

\section{Data Availability}

The data used for calculation in this paper are obtained from the corresponding author upon request.

\section{Conflicts of Interest}

The authors declare that they have no conflicts of interest.

\section{Acknowledgments}

The authors are grateful for the financial support provided by Innovation Team Construction Project of University Scientific Research Platform in Anhui Province (2016-201824) and National Natural Science Foundation of China (41272278). The authors would like to thank Mr. Shi Wenbao and Mr. Liu Shuai for their guidance and help in the process of writing this article. 


\section{References}

[1] Y.S. Pan, L. P. Dai, G. Z. Li, and Z. G. Li, "Study on compound disaster of rock burst and roof falling in coal mines," Journal of China Coal Society, vol. 46, no. 1, pp. 112-122, 2021.

[2] S. Liu, K. Yang, and C. A. Tang, "Mechanism and integrated control of "rib spalling: roof collapse-support instability" hazard chains in steeply dipping soft coal seams," Advances in Materials Science and Engineering, vol. 2021, Article ID 5524591, 20 pages, 2021.

[3] J. X. Yang, C. Y. Liu, Y. Yang, and J. W. Li, "Study of the bearing mechanism of the coal roof and the dimension selection of the room and pillar in the shallow and close distance coal seam," Journal of China University of Mining \& Technology, vol. 42, no. 2, pp. 161-168, 2013.

[4] H. Yan, M. Y. Weng, R. M. Feng et al., "Layout and support design of a coal roadway in ultra-close multiple-seams," Journal of Central South University, vol. 22, no. 22, pp. p4385-4395, 2015.

[5] S. X. Hu, X. L. Xu, S. C. Tian et al., "Optimization of roadway location in lower coal seam from synergy mechanism of contiguous seam mining," Journal of Mining \& Safety Engineering, vol. 33, no. 6, pp. 1008-1013, 2021.

[6] J. Zhao and G. Li, "Pressure-relief mining of the working face under the coal pillar in the close distance coal seams," Geotechnical \& Geological Engineering, vol. 34, no. 4, pp. 10671077, 2016.

[7] X. Liu, X. Li, and W. D. Pan, "Analysis on the floor stress distribution and roadway position in the close distance coal seams," Arabian Journal of Geosciences, vol. 9, no. 2, 2016.

[8] F. Du, R. F. Yuan, J. L. Zheng et al., "Mechanism of abnormal strata pressure of mining under coal pillar in close distance shallow coal seams," Journal of China Coal Society, vol. 42, no. s1, pp. 24-29, 2016.

[9] F. .L. He, K. Lv, X. B. Li et al., "Failure mechanism and control of lower retracement channel in close-distance double-thick coal seams," Shock and Vibration, vol. 2021, no. 11, 19 pages, Article ID 6651099, 2021.

[10] Z. Zhang, M. Deng, J. Bai, S. Yan, and X. Yu, "Stability control of gob-side entry retained under the gob with close distance coal seams," International Journal of Mining Science and Technology, vol. 31, no. 2, pp. 321-332, 2021.

[11] Z. Sun, Y. Wu, Z. Lu, Y. Feng, X. Chu, and K. Yi, "Stability analysis and derived control measures for rock surrounding a roadway in a lower coal seam under concentrated stress of a coal pillar," Shock and Vibration, vol. 2020, no. 1, 12 pages, Article ID 6624983, 2020.

[12] J. Kang, G. Y. Sun, and C. J. Dong, "Overlying strata movement law of ultra-close thin coal seam adopting simultaneous mining face," Journal of Mining \& Safety Engineering, vol. 27, no. 1, pp. 51-56, 2010.

[13] Y. Zhang, C. A. Liu, X. B. Zhang et al., "The influence of ascending mining on the movement character of overlying coal seam in coal seams group," Journal of China Coal Society, vol. 36, no. 12, pp. 1990-1995, 2011.

[14] H. Wu, B. Dai, L. Cheng, R. Lu, G. Zhao, and W. Liang, "Experimental study of dynamic mechanical response and energy dissipation of rock having a circular opening under impact loading," Mining, Metallurgy \& Exploration, vol. 38, no. 2, pp. 1111-1124, 2021.

[15] P. Liu, H. Q. Liu, Q. Ma et al., "Research on evolution rule of inclination fracture field and support technology in close distance and inclined coal seam mining," Geotechnical \& Geological Engineering, vol. 37, no. 10, pp. 2081-2090, 2019.
[16] Z. Cheng, H. Ma, C. Sang et al., "Experimental research on dynamic evolution characteristics of roof movement and mining-induced stress of superimposed mining in a close distance coal seam group," Geotechnical \& Geological Engineering, vol. 39, no. 2, pp. 1-12, 2019.

[17] S. Liu, K. Yang, T. Zhang, and C. Tang, "Rib spalling 3D model for soft coal seam faces with large mining height in protective seam mining: theoretical and numerical analyses," Geofluids, vol. 2020, no. 6, 17 pages, Article ID 8828844, 2020.

[18] Y. J. Yang, S. Ning, J. K. Lv et al., "Study on the laws of overlying strata movement of repeated mining of close distance thick coal seam under large surface water," Geotechnical \& Geological Engineering, vol. 37, no. 2, pp. 3547-3555, 2019.

[19] J. Lu, C. Jiang, Z. Jin, W. Wang, W. Zhuang, and H. Yu, "Three-dimensional physical model experiment of mininginduced deformation and failure characteristics of roof and floor in deep underground coal seams," Process Safety and Environmental Protection, vol. 150, pp. 400-415, 2021.

[20] S. G. Li, Y. Ding, Z. F. An et al., "Experimental research on the shape and dynamic evolution of repeated mining-induced fractures in short-distance coal seams," Journal of Mining \& Safety Engineering, vol. 33, no. 5, pp. 904-910, 2016.

[21] S. Liu, K. Yang, C. Tang, and X. Chi, "Rupture and migration law of disturbed overburden during slicing mining of steeply dipping thick coal seam," Advances in Civil Engineering, vol. 2020, no. 4, 11 pages, Article ID 8863547, 2020.

[22] H. Wu and D. Ma, "Fracture phenomena and mechanisms of brittle rock with different numbers of openings under uniaxial loading," Geomechanics and Engineering, vol. 25, no. 6, pp. 481-493, 2021.

[23] L. H. Tan, T. Ren, L. M. Dou et al., "Analytical stress solution and mechanical properties for rock mass containing a hole with complex shape," Theoretical and Applied Fracture Mechanics, vol. 114, 2021.

[24] F. Cui, C. Jia, and X. P. Lai, "Study on the law of fracture evolution under repeated mining of close-distance coal seams," Energies, vol. 13, no. 22, pp. 1-20, 2020.

[25] Y. L. Tan, T. B. Zhao, and Y. X. Xiao, "Researches on floor stratum fracturing induced by antiprocedure mining underneath close-distance goaf," Journal of Mining Science, vol. 46, no. 3, pp. 250-259, 2010.

[26] Y. C. Xu, S. Q. Liu, Z. X. Liu et al., "Overburden failure laws in working face of short distance thick coal seams group," Journal of Mining \& Safety Engineering, vol. 30, no. 4, pp. 506-511, 2013.

[27] W. Zhang, D. S. Zhang, D. H. Qi et al., "Floor failure depth of upper coal seam during close coal seams mining and its novel detection method," Energy Exploration \& Exploitation, vol. 36, no. 6, pp. 1265-1278, 2018.

[28] J. Li, Y. Huang, J. Li, M. Qiao, and F. Wang, "The influences of key strata compound breakage on the overlying strata movement and strata pressure behavior in fully mechanized caving mining of shallow and extremely thick seams: a case study," Advances in Civil Engineering, vol. 2019, no. 8, 11 pages, Article ID 5929635, 2019.

[29] J. G. Ning, J. Wang, Y. L. Tan et al., "Mechanical mechanism of overlying strata breaking and development of fractured zone during close-distance coal seam group mining," International Journal of Mining Science and Technology, vol. 30, no. 2, pp. 207-215, 2020.

[30] Y. Li, Y. Q. Ren, S. S. Peng et al., "Measurement of overburden failure zones in close-multiple coal seams mining," International Journal of Mining Science and Technology, vol. 31, no. 9, pp. 43-50, 2020. 
[31] D. Ma, S. B. Kong, Z. H. Li et al., "Effect of wetting-drying cycle on hydraulic and mechanical properties of cemented paste backfill of the recycled solid wastes," Chemosphere, vol. 282, 2021.

[32] W. G. Du, J. Chai, D. D. Zhang et al., "Application of optical fiber sensing technology in similar model test of shallowburied and thick coal seam mining," Measurement, vol. 181, no. 3, 2021.

[33] D. Y. Hao, Y. Z. Wu, H. J. Chen et al., "Instability mechanism and prevention technology of roadway in close distance and extra thick coal seam under goaf," Journal of China Coal Society, vol. 44, no. 9, pp. 2682-2690, 2019.

[34] Y. Yu, W. L. Shen, and J. Gao, "Deformation mechanism and control of lower seam roadway of contiguous seams," Journal of Mining \& Safety Engineering, vol. 33, no. 1, pp. 49-55, 2016.

[35] D. Ma, H. Duan, J. Liu, X. Li, and Z. Zhou, "The role of gangue on the mitigation of mining-induced hazards and environmental pollution: an experimental investigation," The Science of the Total Environment, vol. 664, pp. 436-448, 2019.

[36] L. F. Wang, Z. C. Chang, Z. B. Yang et al., "Combined support technology of roadway under mined gob of ultra-distance seams in deep mine," Journal of Mining \& Safety Engineering, vol. 35, no. 4, pp. 686-692, 2018.

[37] Q. H. Huang, Y. P. He, L. B. Luo et al., "Study on the active structure of caved roof and support resistance in shallow buried and ultra-close coal seams mining," Journal of Mining \& Safety Engineering, vol. 35, no. 3, pp. 561-566, 2018.

[38] Y. Lu, C. Y. Liu, J. F. Zhou et al., "Failure structure characteristics of strata with upper thin and lower thick strata in ultra-close coal seams with simultaneous mining and relationship between shield and surrounding rock," Journal of Mining \& Safety Engineering, vol. 34, no. 5, pp. 832-860, 2017.

[39] J. X. Yang, C. Y. Liu, B. Yu et al., "Roof structure of close distance coal strata in multi-gob condition and its effects," Acta Geodynamica et Geomaterialia, vol. 11, no. 4, pp. 351359, 2014.

[40] Y. B. Hou, S. S. He, and S. R. Xie, "Damage and rupture laws of main roof between coal seams with a close distance," Rock and Soil Mechanics, vol. 38, no. 10, pp. 2989-3000, 2017.

[41] Ministry of Coal Industry, Coal Pillar Reservation and Coal Mining Regulations for Buildings, Water Bodies, Railways and Main Roadways, pp. 55-56, China Coal Industry Publishers, Beijing, China, 2017.

[42] A. S. Vesic, "Analysis of ultimate loads of shallow foundations," Journal of the Soil Mechanics and Foundations Division, vol. 99, no. sm1, pp. 45-73, 1973.

[43] D. K. Mccook, "Limit analysis and solid plasticity," Soil Science Society of America Journal, vol. 40, no. 4, pp. 1-4, 1976.

[44] J. C. Zhang and T. Q. Liu, "On depth of fissured zone in seam floor resulted from coal extraction and its distribution characteristics," Journal of China Coal Society, vol. 15, no. 2, pp. 46-55, 1990.

[45] A. H. Wilson, "831145 Stress and stability in coal ribsides and pillars," International Journal of Rock Mechanics and Mining Science \& Geomechanics Abstracts, vol. 20, no. 1, p. A17, 1983.

[46] Z. Q. Wang, P. F. Li, L. Wang, and Y. Gao, "Method of division and engineering use of "three band" in the stope again," Journal of China Coal Society, vol. 38, no. s2, pp. 287-293, 2013.

[47] Q. X. Huang and J. B. Han, "Study on fracture evolution mechanism of shallow-buried close coal seam mining," Journal of Mining \& Safety Engineering, vol. 36, no. 4, pp. 706-711, 2019.
[48] H. Z. Wang, Y. J. Ju, K. K. Qin et al., “A comparative study on floor failure law in deep and short-distance coal seam mining," Journal of Mining \& Safety Engineering, vol. 37, no. 3, pp. 553-560, 2020.

[49] J. L. Xu and J. F. Ju, "Structural morphology of key stratum and its influence on strata behaviors in fully-mechanized face with super-large mining height," Chinese Journal of Rock Mechanics and Engineering, vol. 30, no. 8, pp. 1547-1556, 2011.

[50] M. G. Qian, X. X. Miao, and F. L. He, "Analysis of key block in the structure of voussoir beam in longwall mining," Journal of China Coal Society, vol. 19, no. 6, pp. 557-563, 1994. 